\title{
Gender Roles in the Relationship between Hijrah Intention, Satisfaction, and Islamic-Bank Customer Loyalty
}

\author{
Fetria Eka Yudiana ${ }^{1 *}$, Hadri Kusuma² and Ibnu Qizam ${ }^{3}$ \\ ${ }^{I}$ Department of Sharia Finance and Banking Faculty of Economic and Islamic Business, \\ IAIN Salatiga, Central Java 50716, Indonesia \\ ${ }^{2}$ Faculty of Business and Economics, Universitas Islam Indonesia, Yogyakarta 55283, Indonesia \\ ${ }^{3}$ Faculty of Economics and Business, UIN Syarif Hidayatulah, Jakarta, 15412, Indonesia
}

\begin{abstract}
This study aimed to analyze the differences between gender roles and the influence of hijrah intention and satisfaction on customer loyalty in Islamic banks. The data was collected from the Indonesian Islamic bank customers using convenience sampling. A total of 360 out of 927 questionnaires were received and sent back online. The hypothesis was tested using Structural Equation Model (SEM) with Smart-PLS. The variable indicators of interest were reflective and adapted from some previous literature. Furthermore, the data had satisfied convergent and discriminant validity requirements. The results showed that the Islamic bank customer loyalty routes differ between men and women. Satisfaction encourages hijrah intention without directly affecting customer loyalty in males. However, satisfaction strongly determines loyalty rather than hijrah intention for women. In the full model, hijrah intention serves a stronger mediating role on the satisfaction and loyalty relationship than the mediating role of satisfaction on the hijrah intention-loyalty relationship.
\end{abstract}

Keywords: Customer loyalty, customer satisfaction, gender role, Hijrah intention, Islamic bank

ARTICLE INFO

\section{Article history:}

Received: 16 June 2021

Accepted: 8 September 2021

Published: 8 December 2021

DOI: https://doi.org/10.47836/pjssh.29.4.28

E-mail addresses:

fetria_belsa@yahoo.com (Fetria Eka Yudiana)

hkusuma@uii.ac.id (Hadri Kusuma)

qzami68@gmail.com (Ibnu Qizam)

*Corresponding author

\section{INTRODUCTION}

In the Islamic banking industry, the banking segment develops dynamically. Islamic differ from conventional banks due to the principle of profit-and-risk sharing. Still, they can attract non-Muslim customers since they perceive it fairer (Saleh et al., 2017). Despite the enormous potential, people consider Islamic banks less popular and experienced 
than conventional ones. Because of the challenging environment, developing and maintaining customer loyalty is important for long-term survival and positively affects business developments, including saving amounts, operating and marketing costs, customer retention rates, and future income (Bloemer et al., 1998; Saleh et al., 2017).

Based on relationship marketing and social exchange theory, the company and customers continue interacting with reward exchange. The parties in relationships evaluate them in several contexts, including behavior, short-term injustice, and longterm mutual benefits. Therefore, evaluating and developing factors like customer satisfaction and loyalty is vital. Since having loyal customers is critical, customer loyalty in Islamic banking has received a lot of concern and attention from recent literature (Hoque et al., 2019; Saleh et al., 2017; Rehman \& Shabbir, 2010; Suhartanto et al., 2019). Although previous studies have mostly explored the satisfaction and service quality variables as top priorities in customer loyalty, most have focused on service quality and customer satisfaction to determine and drive customer loyalty (Saleh et al., 2017; Rehman \& Shabbir, 2010; Suhartanto et al., 2019). Social exchange theory does not merely measure rewards using economic or material, and social criteria. Most previous studies have not fully considered the transcendental and spiritual aspects (Riyadi, 2021). Accounting for the spiritual aspects of consumer behavior is critical since, as an important sub-cultural factor, religion affects satisfaction. It is also a sacred value that strongly influences emotions, experiences, thoughts, behavior, and psychology. Therefore, some literature recommends accounting for religious factors in marketing studies.

Although some literature proves that religion influences consumer behavior, several studies show that religious variables do not significantly affect some of its aspects (Haron et al., 1994; Kaynak \& Harcar, 2005), implying a pervasive influence (Lubis et al., 2021). In reality, heterogeneity exists among individuals in the same religion who are faithful and committed to practicing it. Furthermore, how religion influences customer behavior highly depends on the level of commitment each shows by referring to it and reflecting their attitudes and religious behavior. Therefore, religion affects consumers' intention to behave.

In customer-loyalty literature, one very important thing worth considering is someone's intention to behave 'loyally' to Islamic banks and their influence. In fact, studies have proven that how strong the intention is influences loyalty (Haider et al., 2018). While, in general, intention critically determines customer attitudes and behavior, only a few studies have examined it (hijrah-intention variable) as a determinant of customer loyalty in Islamic banking (Hoque et al., 2019). This context inspires hijrah (a strong commitment to a change of Islamic-based betterness), an Islamic value. In general, hijrah aims to carry out religious teachings in intention, commitment and leave what religion prohibits. Therefore, its variable can 
fill the gaps in the customer loyalty study with management and marketing studies focusing on gender differences. Various perspectives of gender roles have been investigated, including work environments (Babin \& Boles, 1998; Yavas et al., 2008), ethical perceptions (Ergeneli \& Arrkan, 2002), and the role of stress (Karatepe \& Tekinkus, 2006). Studies in management and marketing contexts (Babin \& Boles, 1998; Karatepe \& Tekinkus, 2006) concluded that while men are task-or-goal-oriented, women are more relationship-oriented (communal).

The influence of gender on human interactions has been studied in social life. However, marketing literature on gender interactions in service-trading situations, their effects on relationship development and customer loyalty is still limited. Similarly, there are no studies on gender roles in customer loyalty of Islamic banks, though consumer loyalty is a popular study topic. Because of the increased participation of women in the workforce, interest in gender differences in business decision-making under risk has emerged. Many studies have found gender differences in attitude and behavior towards risk (Powell \& Ansic, 1997). However, stereotypical beliefs about them prevail despite recent contradictory evidence (Venkatesh \& Morris, 2000). The findings suggest that these gender differences really matter in business decision-making or risky business activities. However, the previous researchers do not consider them due to their different methodologies-especially when structuring questionnaires - and their various levels of competency and understanding. Consequently, the study aims to predict the differences in routes across gender and the relationship between Islamic banks' satisfaction, hijrah intention, and customer loyalty. The findings would help Islamic bank practitioners understand the paths of satisfaction for potential customers and provide new insights (hijrah intention) on loyalty. This study differed from the previous ones because the hijrah-intention variable used significantly affected Islamic bank customer loyalty. The following sub-sections covered literature review and hypotheses development, methods, results, discussion, and conclusions.

\section{LITERATURE REVIEW AND HYPOTHESES DEVELOPMENT}

\section{Islamic-Bank Customer Loyalty}

Recently, loyalty has reflected many meanings, with some experts defining it in several aspects, resulting in varied judgments (Fournier \& Mick, 1999; Oliver, 1999). There have been substantial disagreements about the definition or nature of loyalty. However, it is generally defined as a relationship (from very superficial to very strong) between an actor and an entity that demonstrates their behavioral or psychological loyalty to the entity despite other alternatives. It is also defined as a commitment to re-purchase preferred products and/or services from time to time, instead of adhering to marketing efforts offered from competitors to persuade customers to switch to other banks (AldasManzano et al., 2011; Abou-Youssef et 
al., 2015). Several studies on customer loyalty antecedents have documented the satisfaction-loyalty relationships in varied aspects (Dick \& Basu, 1994; Fournier \& Mick, 1999; Johnson et al., 2006; Johnson \& Morris, 2008; Muniz \& O'Guinn, 2001; Mohamed et al., 2020; Oliver, 1999).

It is important to maintain customer loyalty for Islamic banks in the service industry. While many factors affect customer loyalty, satisfaction is the main one (Soelasih \& Sumani, 2021). After consumption, customers become satisfied or dissatisfied, making them loyal. Still, the hijrah intention strongly determines loyalty from the inside-of-the-customer perspective. Several channels can be used to develop empirical customer loyalty (Suhartanto et al., 2019). However, the satisfaction path is the most often used. Many studies have concluded that satisfying a customer positively and significantly influences loyalty (Abror et al., 2019; Meesala \& Paul, 2018).

Service providers must align relevant services with user interests, emotionally and rationally retain, and use them to attract diverse customers. Compared to goods, service consumers have more customer loyalty (Panther \& Farquhar, 2004). A bank-customer loyalty study established that customers with a "completely satisfied" statement were $42 \%$ more likely to be loyal than those with "satisfied" (Jones, 1996). Many experts assert that only the highest level of satisfaction (very satisfied) can be acceptable performance. Besides, satisfaction and loyalty do not surrogate each other (Bloemer \& Kasper, 1995;
Oliver, 1999). A customer can be loyal but not very satisfied or very satisfied but disloyal.

\section{Gender in Consumer Behavior and Customer Loyalty Framework}

Men and women, while shaping brand loyalty, behave differently. Although women have more intense forms of involvement than men, gender differences in the decision-making process can affect their attitudes and loyalty levels (Melnyk et al., 2009). Furthermore, gender differences affect their perceptions of masculinity and femininity in products, making gender identity an important role (Fischer \& Arnold, 1994). However, several previous studies have varied results about how gender difference influences intention. For example, while masculinity significantly predicts consumers' purchase intention (Glavee-Geo et al., 2017), femininity is more important (Fischer \& Arnold, 1994).

Other studies have also established that gender differences significantly affect customer loyalty which differs among male and female customers (Melnyk et al., 2009). While females develop and maintain their loyalty individually, males are more loyal in groups (companies). Moreover, females are more likely to maintain social relationships, including those with a company (loyal), men (Cross et al., 2000), and they also have a higher interdependent self-construal. Their loyalty differs significantly (Melnyk et al., 2009), with women being more likely to be individual while men being inclined towards groups. 
Based on the previous study results, there are more gender role differences in customer loyalty, especially mobile banking (Haider et al., 2018 Zoghlami et al., 2018). First, males are more influenced by selfexpression and reliability, while females by privacy and innovation (Kalinić et al., 2019; Zoghlami et al., 2018). Second, other studies use gender as a variable moderator, indicating that gender differences strongly influence the strength of the relationship between mobile variables (Glavee-Geo et al., 2017; Haider et al., 2018).

\section{HYPOTHESES DEVELOPMENT}

Hijrah means a change in Muslim's attitude and behavior to pursue a better life under AlQuran and Al-Hadits for the blessing from Allah. Since it reflects individual religious orientation (Yudiana et al., 2021), its intention is important for Muslim behavior. It intends to perform religious teachings in intention, commitment, and efforts to leave what religion (Islam) prohibits. In the Islamic banking context, not all Muslims follow Islamic provisions against usury or bank interest. In a dual banking system like Indonesia, various backgrounds and motives may prevail and make a Muslim loyal to conventional bank services. Thus, the strong desire to quit conventional banks and switch to Islamic banks based on his faith is called hijrah intention.

In this respect, hijrah's intention differs from religiosity, which reflects a general term, while hijrah is specific. Religiosity is the degree to which a person uses religious values, beliefs, and practices in everyday life (Worthington et al., 2011), and it has different levels among its adherents. Some Muslim communities with a comparable level of religiosity may have different hijrah intentions towards Islamic banks. Consequently, it is influenced by many things, as stated in the Theory of Planned Behavior (TPB), which states that 'a consumer's intention is influenced by attitudes, subjective norms, and perceived behavior control.'

Gender does not moderate variables such as e-service quality, e-satisfaction, and e-trust on e-loyalty (Ladhari \& Leclerc, 2013). From a broader perspective, there are two explanations on the influence of gender roles. First, women and men focus on different aspects of service and satisfaction (Iacobucci \& Ostrom, 1993). For example, although women are more relationship-oriented and very detailed, men are more task-or-goal oriented but focus less on details (Karatepe \& Tekinkus, 2006; Yavas et al., 2008). However, the study about service marketing and gender role differences is still limited (Matzler et al., 2008; Sánchez-Hernández et al., 2010). Second, assessing how service-quality dimensions affect satisfaction without considering gender moderation role mislead bank managers practically when setting appropriate priorities.

Two important findings of gender as moderating roles emerged, including the influence of empathy and reliability on satisfaction, where those female customers were more influenced than males. It confirms that they are more relationship-oriented 
and concerned with social interaction. Private German banks are more concerned with interpersonal relationships and communication than males and tend to offer positive word of mouth (Yavas et al., 2008).

More significant differences on how men's and women's roles influence social norms and adoption intentions emerged. When the sample was combined between men and women among users of online banking services in Pakistan, gender roles were not significant (Glavee-Geo et al., 2017). Although the intention of men is significantly influenced by perceived usefulness and self-expression, credibility matters more to women. Still, gender differences do not affect social norms on the level of adoption of m-banking services in India (Haider et al., 2018).

Gender roles have a moderating effect on the relationship between ease of use and attitudes towards adopting mobile banking in India, though it is stronger for women (Chawla \& Joshi, 2018). Though women value security or respect privacy, quality information, and trust m-banking application, men value security or respect privacy, reliability, and ease of use (Zoghlami et al., 2018). Gender moderates the effects of performance and effort expectancy on behavior intention in studying mobile-microfinance services in Kenya (Warsame \& Ireri, 2018). Men and women are easily influenced by their social environment and personal innovativeness, respectively (Kalinić et al., 2019).

Loyalty is a complex multidimensional concept in the consumer-behavior model. In the context of brands, it is a psychological commitment to a particular brand and the result of individual expectations about service consumption. Customer expectations affect satisfaction and contribute to user loyalty directly and indirectly (Rufín et al., 2012). Therefore, it is important to analyze loyalty from the cognitive-affective dimension while developing it (Oliver, 1999), and the cognitive always precedes the affective aspect. Meanwhile, another study explained that cognitive is a precursor to the affective component (Leverin \& Liljander, 2006). Cognitive stage loyalty usually depends on some information grasped from comparing one brand or product to the others. For example, an Islamic bank consistently tries to provide more competitive prices than its competitors.

This study examined how gender roles differ between men and women, rather than using gender as a moderating variable. From the marketing strategy perspective, a customer's decision-making role largely determines the marketing strategy described in the elaboration model or the reasoned versus unintentional path described by the prototype willingness model (Ohtomo $\&$ Hirose, 2007). Male characters are more task-oriented and focused on the dimensions that help them complete tasks effectively. In this sense, task centricity and goal orientation dominate men (Saeed \& Abdinnour-Helm, 2008). Since men are more willing to spend more effort to overcome constraints and challenges to pursue their goals, they, therefore, judge things primarily on functionality (Venkatesh $\&$ Morris, 2000; Venkatesan et al., 2007). 
In the context of the male roles, they are more driven by the cognitive component. Since cognitive phase loyalty is based on prior knowledge or experience, it is stronger (Yi \& La, 2004). Furthermore, real experiences for men are stronger than for women. Therefore, it is reasonable to predict that expectations from cognitive processes during Islamic banking services positively affect male-user loyalty. The hypotheses are as follows:

H1a: For men (male's role), the stronger hijrah intention, the stronger its positive influence on loyalty.

H1b: For men (male's role), the more they feel satisfied, the stronger their positive effect on loyalty.

H1c: For men (male's role), the more they feel satisfied, the stronger their hijrah intention will be.

H1d: For men (male's role), hijrah intention becomes a mediating variable on how satisfaction and loyalty relate.

In the consumers' context, women focus more on the prices of products and services and are involved in purchasing than results (Kwateng et al., 2019). Service quality can be defined as 'a global assessment or attitude related to the excellence of a service,' (Parasuraman et al., 1993) and is an antecedent of satisfaction in shortservice messages (Lai, 2004). It is similar to perceived quality in marketing and significantly affects satisfaction (McKinney et al., 2002). Women emphasize external supporting factors more. Furthermore, gender moderates the relationship between service quality and customer satisfaction
(Jin et al., 2013; Ramanathan et al., 2016). Female customers are more socially oriented, have communal attention, and care about relationships and their quality (Ndubisi, 2006).

Following this difference, women are more sensitive to relational aspects. Customer satisfaction directly relates to loyalty (Meesala \& Paul, 2018). Although some literature on satisfaction-loyalty relationships does not consider gender, others suggest that women show a higher direction on the effect of satisfaction and loyalty (Assaker et al., 2015). Besides, in online financial services, women report higher online service quality levels, e-satisfaction, e-trust, and e-loyalty than men (Ladhari \& Leclerc, 2013). Based on these results, the following hypotheses are formulated.

H2a: For women (women's role), the more they feel satisfied, the stronger the positive effect on loyalty.

$\mathrm{H} 2 \mathrm{~b}$ : For women (women's role), the stronger the hijrah intention is, the more the satisfaction they get to Islamic banks.

H2c: For women (women's role), the stronger the hijrah intention is, the higher their loyalty to an Islamic bank.

H2d: For women (women's role), satisfaction mediates the relationship between hijrah intention and loyalty.

\section{METHODS}

\section{Data Materials}

This study used a survey method through questionnaires and a convenience approach 
to collect data. Overall, the used approach fitted because the population was unknown, large, and showed several opinions, attitudes, and behaviors. It necessitated an effective and easy way to capture those phenomena from potential respondents, particularly taking a sample using a convenience approach through online questionnaires.

Questionnaires were distributed in Google Form to Islamic bank customers from all the Indonesian provinces to collect data. Determining potential respondents depended on contacts on the selected WhatsApp group (WAG). Since they were study groups, seminars \& workshops related to Islamic economics and banking, and WAGs with Islamic economics and banking experts, we judged that its people had a great opportunity to become Islamic bank customers. As a result, 320 out of the 927 questionnaires sent to prospective respondents were filled in and sent back to the authors, making the response rate $38.8 \%$.

Google Form link was sent to the WAG number personally to obtain a good response rate and continued exerting efforts to make the prospective respondents interested in filling in and resubmitting the online questionnaires, specifically by giving some souvenirs. The sample size used had ten times the minimum size of question-item number from all the variables of interest (Hair et al., 2018). The 28 provinces were represented by 214 and 146 women and men, respectively. Generally, the respondents' age ranged from 18 to 30,31 to 50 , and more than 50 years in $50.55 \%, 41.38 \%$, and $8.07 \%$ percentiles, respectively. The respondents' occupations were civil servants, selfemployed/ entrepreneurs, BUMN/BUMD (state-owned enterprises) employees, students, and private employees in $54.73 \%$, $7.5 \%, 5.55 \%, 8.07 \%$, and $0.55 \%$, while the rest came from other fields. The bank usage history groups them into two as only using Islamic banks (70.28\%) and using both conventional and Islamic banks (29.72\%).

\section{Measurement}

The variables that reflect satisfaction, hijrah intention, and customer loyalty were measured on a five-point Likert scale, ranging from 1 (strongly disagree) to 5 (strongly agree). Table 1 indicates that they are nature-reflective and adapted from several previous studies, including satisfaction (Tiliouine \& Belgoumidi, 2009), hijrah intention (modification of TPB theory), and loyalty variables (Kashif et al., 2015; Mohsan et al., 2011).

Table 1

Data measurement

\begin{tabular}{ll}
\hline Variable \& Major References & Items \\
\hline Satisfaction & 1. I am satisfied with Islamic bank products \\
( Mohsan et al., 2011; & 2. I am satisfied with the services of Islamic banks \\
Kashif et al., 2015) & 3. Islamic banks can always live up to my expectations \\
& 4. Islamic banks always provide a pleasant experience \\
\hline
\end{tabular}


Table 1 (Continue)

\begin{tabular}{|c|c|}
\hline Variable \& Major References & Items \\
\hline $\begin{array}{l}\text { Hijrah Intention } \\
\text { (Yudiana, 2021) }\end{array}$ & $\begin{array}{l}\text { 1. I really want to avoid sin because of usury } \\
\text { 2. I really want to have the blessing of living in the world } \\
\text { 3. I really want to get the blessings in the hereafter } \\
\text { 4. I convince myself that bank interest is usury } \\
\text { 5. I convinced myself that bank interest is haram } \\
\text { 6. Islamic banks are fairer } \\
\text { 7. I want to avoid bank interest }\end{array}$ \\
\hline $\begin{array}{l}\text { Loyalty Intention } \\
\text { (Kishada, 2013; Mohsan et al., } \\
\text { 2011; Vyas \& Raitani, 2014; } \\
\text { Wang et al., 2018) }\end{array}$ & $\begin{array}{l}\text { 1. I intend to use Islamic banks } \\
\text { 2. I intend to use Islamic banking services } \\
\text { 3. I intensely recommend Islamic banks to friends } \\
\text { 4. I intend to recommend Islamic banks to families } \\
\text { 5. I will be loyal to Islamic banks } \\
\text { 6. I tend to use Islamic banks than conventional banks } \\
\text { 7. I am committed to continuing using Islamic bank } \\
\text { products } \\
\text { 8. I am committed to using Islamic banking services } \\
\text { appropriately }\end{array}$ \\
\hline
\end{tabular}

The validity and reliability of the data and study instruments were tested before hypotheses. Table 2 presents the loading factor of each construct item that exceeds 0.5 (Hair et al., 2018), making all the question items have high convergent validity. The validity indicators also showed greater values than the threshold literature recommended. Since all squareroot AVE values were greater than the other coefficients for the same construction, a good discriminant validity came out (Gefen et al., 2000). It is determined by the cross- loading value of each indicator toward the variable. Seemingly, the correlation between measurement items was greater than other constructs' values (See Table 3). Moreover, the root AVE value of each variable (either male or female roles) was lower than the correlation of each independent variable to loyalty and higher than the correlation between the independent variables and others. Finally, composite reliability (CR) was greater than 0.7 and Cronbach alpha above 0.7 , showing that the results were reliable.

Table 2

Reliability dan validity indicators

\begin{tabular}{llcc}
\hline Variables & Item & Factors Loading Men & Factors Loading Women \\
\hline Satisfaction & $\mathrm{KP}_{1}$ & 0,854 & 0,894 \\
$\mathrm{CA}=0,892$ & $\mathrm{KP}_{2}$ & 0,805 & 0,889 \\
$\mathrm{CR}=0,920$ & $\mathrm{KP}_{3}$ & 0,782 & 0,811 \\
$\mathrm{AVE}=0,698$ & $\mathrm{KP}_{4}$ & 0,854 & 0,895 \\
& $\mathrm{KP}_{5}$ & 0,877 & 0,904 \\
\hline
\end{tabular}


Table 2 (Continue)

\begin{tabular}{lccc}
\hline Variables & Item & Factors Loading Men & Factors Loading Women \\
\hline & $\mathrm{HI}_{1}$ & 0,721 & 0,861 \\
Hijrah Intention & $\mathrm{HI}_{2}$ & 0,649 & 0,840 \\
$\mathrm{CA}=0,784$ & $\mathrm{HI}_{3}$ & 0,750 & 0,817 \\
$\mathrm{CR}=0,843$ & $\mathrm{HI}_{4}$ & 0,540 & 0,502 \\
$\mathrm{AVE}=0,644$ & $\mathrm{HI}_{5}$ & 0,689 & 0,658 \\
& $\mathrm{HI}_{6}$ & 0,613 & 0,621 \\
& $\mathrm{HI}_{7}$ & 0,646 & 0,686 \\
\hline & $\mathrm{L}_{1}$ & 0,775 & 0,835 \\
& $\mathrm{~L}_{2}$ & 0,799 & 0,825 \\
Loyalty & $\mathrm{L}_{3}$ & 0,783 & 0,793 \\
CA $=0,929$ & $\mathrm{~L}_{4}$ & 0,811 & 0,833 \\
CR $=0,940$ & $\mathrm{~L}_{5}$ & 0,775 & 0,776 \\
AVE $=0,637$ & $\mathrm{~L}_{6}$ & 0,834 & 0,875 \\
& $\mathrm{~L}_{7}$ & 0,805 & 0,852 \\
& $\mathrm{~L}_{8}$ & 0,804 & 0,863 \\
& $\mathrm{~L}_{9}$ & 0,794 & 0,707 \\
\hline
\end{tabular}

Note: $\mathrm{CA}=$ Cronbach's Alpha; $\mathrm{CR}=$ Composite Reliability; $\mathrm{AVE}=$ Average Variance Extracted

Table 3

Discriminant validity

\begin{tabular}{lccc}
\hline Variables & Hijrah Intention & Satisfaction & Loyalty \\
\hline \multicolumn{2}{c}{ Men } \\
\hline Hijrah Intention & 0,802 & 0,880 & \\
Satisfaction & 0,692 & 0,693 & 0,859 \\
Loyalty & 0,879 & & \\
\hline \multicolumn{2}{c}{ Women } \\
Hijrah Intention & 0,802 & 0,880 & \\
Satisfaction & 0,692 & 0,693 & 0,859 \\
Loyalty & 0,879 & &
\end{tabular}

\section{RESULTS}

\section{Statistical Analysis}

The characteristics of the respondents were presented based on gender, age, latest education, occupation, and income of the respondents. Demographic data showed that $57.5 \%$ (about 207) of the respondents were female. Respondents of 31 to 50 years were $41.38 \%$ (149), while $8.06 \%$ (29) were over 50 years. $39.72 \%, 28.07 \%$, and $17.77 \%$ of respondents had a Master's level (S2, 101), an undergraduate education (S1, 64), and doctoral education, respectively. Since most respondents work as civil servants, 
non-lecturers \& teachers and lecturers/ teachers were $28.07 \%$ (101) and $26.66 \%$ (96), respectively. The rest came from Army/Police, students, business people and entrepreneurs, private employees, and other types of jobs. While $70.28 \%$ of respondents were only customers of Islamic banks, $29.72 \%$ belonged to conventional Islamic banks. Partial-least-square structural equation models (PLS) tested the structural model and determined the significance of the hypothesized relationship. Three models of this study had been tested: the full model $(\mathrm{n}=360)$, the male role $(\mathrm{n}=153)$, and the female role $(\mathrm{n}=207)$, as in Table 4.

Table 4 shows that for the male role, the statistically significant antecedent of the loyalty model was hijrah intention $(\beta=$ $0.772 ; \mathrm{p}$-value $<0.01)$. Satisfaction predicted hijrah intention $(\beta=0.585$; $\mathrm{p}$-value $<0.01)$ positively but could not determine loyalty ( $\beta=0.086$; $p$-value $>0.05)$. Furthermore, the hijrah-intention variable mediated the relationship between satisfaction and loyalty $(\beta=0.451 ; p$-value $<0.05)$ fully. The results of the structural model testing (to see the goodness-of-fit model) showed the value of R-square $=0.681$ and Adjusted-R square $=0.677$, concluding that the satisfaction construct and hijrah intention can explain $67.7 \%$ of the variability of the loyalty construct on male roles.

In the male customer group, hijrah intention-built loyalty on its variable, thus strongly influencing loyalty. Significantly, it directly affected male customer loyalty (H1a) and fully mediated how satisfaction and loyalty (H1d) related. On the other hand, for male customers, the satisfaction variable did not significantly affect loyalty (H1c). Because men are more driven by the cognitive component ( $\mathrm{Yi} \& \mathrm{La}$, 2004), a banking system supports male customers' concerns when using the banking facilities they need. It means that the initial intention to be loyal to Islamic banks is more influential for male customers. These results fully support the theory of planned behavior, that is, intention can predict behavior. Based on this, how loyal Islamicbank customers are is determined by how strong the intention of male customers is: the stronger their hijrah intention is, the higher their loyalty to Islamic banks. Besides, satisfaction significantly influences Hijrah intention in the male role (H1c). The results of the bootstrapping test are shown in Figure 1.

Table 4

Results of testing hypotheses

\begin{tabular}{|c|c|c|c|c|}
\hline Measurement & $\begin{array}{c}\text { Full Model } \\
\text { Coefficient } \\
\text { (t-stat) }\end{array}$ & $\begin{array}{c}\text { Male } \\
\text { Coefficient } \\
\text { (t-stat) }\end{array}$ & $\begin{array}{c}\text { Female } \\
\text { Coefficient } \\
\text { (t-stat) }\end{array}$ & $\begin{array}{l}\text { Hypotheses } \\
\text { Result }\end{array}$ \\
\hline Hijrah Intention $\rightarrow$ Loyalty & $\begin{array}{c}0.654 * * * \\
(12.199)\end{array}$ & $\begin{array}{l}0.772 * * * \\
(13.165)\end{array}$ & & $\begin{array}{c}\text { H1a } \\
\text { Supported }\end{array}$ \\
\hline $\begin{array}{l}\text { Satisfaction } \rightarrow \text { Hijrah } \\
\text { Intention }\end{array}$ & $\begin{array}{l}0.708 * * * \\
(17.173)\end{array}$ & $\begin{array}{l}0.585^{* * *} * \\
(9.193)\end{array}$ & & $\begin{array}{c}\text { H1b } \\
\text { Supported }\end{array}$ \\
\hline
\end{tabular}


Table 4 (Continue)

\begin{tabular}{|c|c|c|c|c|}
\hline Measurement & $\begin{array}{c}\text { Full Model } \\
\text { Coefficient } \\
\text { (t-stat) }\end{array}$ & $\begin{array}{c}\text { Male } \\
\text { Coefficient } \\
\text { (t-stat) }\end{array}$ & $\begin{array}{l}\text { Female } \\
\text { Coefficient } \\
\text { (t-stat) }\end{array}$ & $\begin{array}{l}\text { Hypotheses } \\
\text { Result }\end{array}$ \\
\hline Satisfaction $\rightarrow$ Loyalty & $\begin{array}{l}0.252 * * \\
(4.675)\end{array}$ & $\begin{array}{c}0.086 \\
(1.346)\end{array}$ & & $\begin{array}{l}\text { H1c Not } \\
\text { Supported }\end{array}$ \\
\hline $\begin{array}{l}\text { Satisfaction } \rightarrow \text { Hijrah } \\
\text { Intention } \rightarrow \text { Loyalty }\end{array}$ & $\begin{array}{c}0.463 * * * \\
(9.409)\end{array}$ & $\begin{array}{l}0.451^{* *} \\
(7.059)\end{array}$ & & H1d Supported \\
\hline $\begin{array}{l}\text { Hijrah Intention } \rightarrow \\
\text { Satisfaction }\end{array}$ & $\begin{array}{l}0.708 * * * \\
(16.778)\end{array}$ & & $\begin{array}{l}0.708 * * * \\
(16.477)\end{array}$ & H2b Supported \\
\hline $\begin{array}{l}\text { Hijrah Intention } \rightarrow \\
\text { Loyalty }\end{array}$ & $\begin{array}{l}0.654 * * * \\
(12.199)\end{array}$ & & $\begin{array}{c}0.654 * * * \\
(11.643)\end{array}$ & H2c Supported \\
\hline Satisfaction $\rightarrow$ Loyalty & $\begin{array}{c}0.252 * * * \\
(4.675)\end{array}$ & & $\begin{array}{l}0.252 * * \\
(4.331)\end{array}$ & H2a Supported \\
\hline $\begin{array}{l}\text { Hijrah intention } \rightarrow \\
\text { Satisfaction } \rightarrow \text { Loyalty }\end{array}$ & $\begin{array}{l}0.178 * * * \\
(4.448)\end{array}$ & & $\begin{array}{c}0.178^{* *} \\
(4.195)\end{array}$ & H2d Supported \\
\hline $\begin{array}{l}\text { Adjusted } \mathrm{R}^{2} \\
\mathrm{R}^{2}\end{array}$ & $\begin{array}{l}0.722 \\
0.725\end{array}$ & $\begin{array}{l}0.677 \\
0.681\end{array}$ & $\begin{array}{l}0.722 \\
0.725\end{array}$ & - \\
\hline
\end{tabular}

Note: $\mathrm{p}<0.05 ; * * \mathrm{p}<0.01 ; * * * \mathrm{p}<0.001$

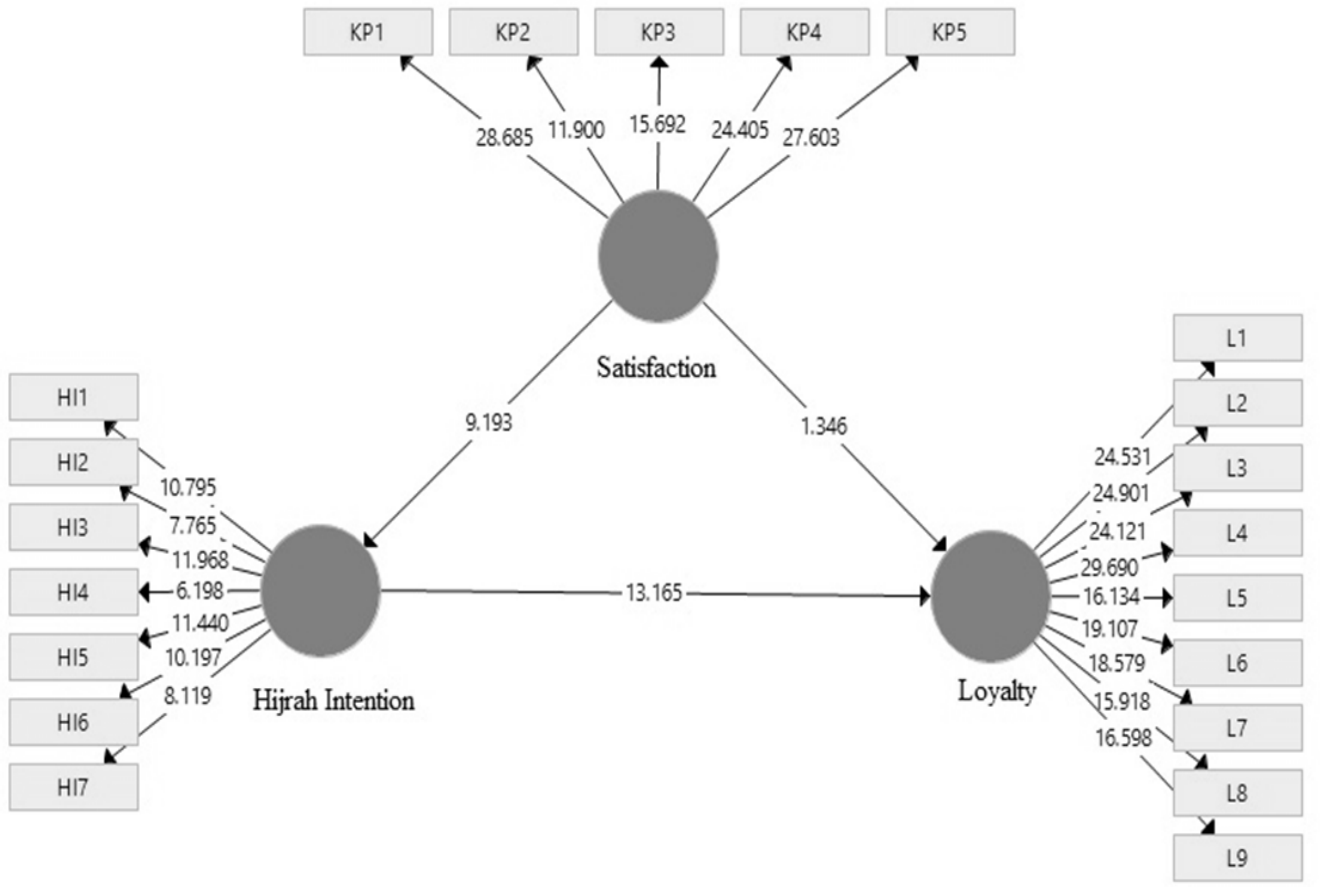

Figure 1. The role of the male in the satisfaction-Hijrah intention-loyalty relationship 
In the women's group, hijrah intention and satisfaction as the antecedents of the loyalty model were all statistically significant. Hijrah intention significantly predicted loyalty $(\beta=0.654$; $p$-value $<0.01$ ) positively and satisfaction with loyalty $(\beta=$ 0.252 ; $p$-value $<0.05)$. It did the same with satisfaction $(\beta=0.708$; $p$-value $<0.01)$, which still partially mediated between hijrah intention and loyalty $(\beta=0.178$; p-value $<0.05)$. While testing the structural model (female role) to see the goodness-offit model, the results indicated that R-square $=0.725$ and Adjusted-R square $=0.722$, meaning that the constructs of satisfaction and hijrah intention could account for $72.2 \%$ of the variability of the loyalty construct in women's roles.

The satisfaction variable greatly affects the loyalty to Islamic banks (H2a) for female customers. Uniqueness and social interaction can encourage satisfaction, which will form loyalty in line with these findings (Noble et al., 2006). These results suggested that women process more detailed information (Karatepe \& Tekinkus, 2006; Yavas et al., 2008). They can emphasize service dependency and the accuracy of the information, ultimately affecting their satisfaction and loyalty. It harmonizes with the results, which prove that the satisfaction variable significantly and partially mediated the relationship between hijrah intention and loyalty (H2d). Hijrah's intention of female customers can affect loyalty directly (H2c) or indirectly through satisfaction. Besides, these results harmonize with previous studies on how the satisfaction variable partially mediates loyalty (Bei \& Chiao, 2006; Bloemer \& Kasper, 1995; Bloemer et al., 1998; Choi, 2009; Cronin et al., 2000; Mosahab et al., 2010). Satisfaction on loyalty strongly affects the role of women than hijrah intention. The results of the bootstrapping test are depicted in Figure 2.

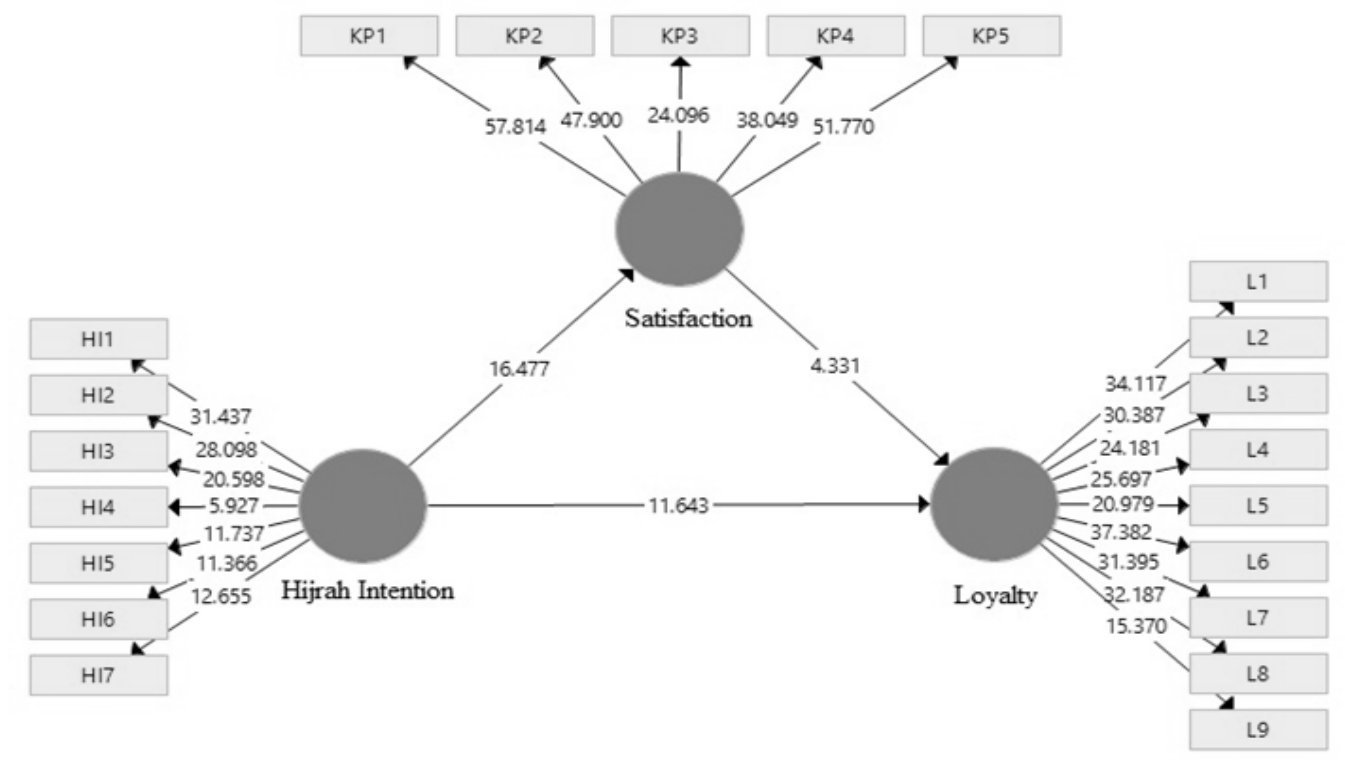

Figure 2. The female's role in the Hijrah intention-satisfaction-loyalty relationship 
In the full model (male and female) (see Table 4), the test results show that hijrah intention more strongly mediates between satisfaction and loyalty $(\beta=0.463$, $p$-value $<0.05)$ than how satisfaction mediates it and loyalty $(\beta=0.178$, p-value $<0.05)$.

\section{DISCUSSIONS}

The characteristics of loyalty among men and women vary, and men can cancel out theirs with satisfaction variables. Men can be loyal to Islamic banks without getting satisfaction from the products and services in case their hijrah intention is strong enough, which dominantly affects loyalty. Similarly, they can be disloyal despite getting satisfaction if they lack a strong hijrah intention. Islamic banks solely depend on trust, and the hijrah intention significantly determines the satisfaction of female customers. The satisfaction variable is complementary and reveals partial mediation. It means that hijrah intention and satisfaction for women complement one another in building Islamic bank loyalty. Women with a strong hijrah intention assimilate the product and service of Islamic banks into their expectations, lead to a maximum positive assessment (satisfaction) and increase their loyalty, which confirms the Assimilation-Contrast Theory that "people with hijrah intention will have a threshold for acceptance and rejection.' They increase expectations to make their difference and performance small and enter the customer acceptance threshold, encouraging satisfaction and loyalty.

\section{CONCLUSIONS}

This study investigated how gender roles related to hijrah intention, satisfaction, and Islamic bank customer loyalty. The results showed that the male and female customer loyalty models differed directly on hijrah intention and satisfaction. Furthermore, male customers were more loyal to Islamic banks than females (from attitude loyalty) and were inclined to have the latent-loyalty. However, satisfaction mostly affected loyalty in females, though the strength of their hijrah intention also mattered. In addition, they were sensitive to the quality of services that provided satisfaction to be sustainable and loyal to an Islamic bank. Consequently, the positive attitude formed from the hijrah-intention effect was less significant than satisfaction.

The results suggest that gender is critical in how Hijrah Intention, satisfaction, and Islamic bank customer loyalty are related and provided empirical support for previous studies on customer loyalty (Ndubisi, 2006). Female customers were more than men, and their satisfaction resulted when they were more loyal as the banks met their expectations. However, for males, satisfaction further encouraged their intention to move (hijrah) to Islamic banks. These results also imply dormancy in the influence of hijrah intention in increasing customer loyalty for men, making them demonstrate the latent-loyalty type. Latent loyalty reflects a strong attitude with weak re-purchases (Dick \& Basu, 1994). It is attributed to the non-attitudinal factor influences, which in determining re- 
purchase or Islamic bank loyalty, are fairly strong or tend to be stronger than attitude.

Since the hijrah intention for female customers encouraged a positive attitude and affected satisfaction, it influenced their loyalty. Furthermore, women are naturally emotional or expressive, which supports the hijrah intention, which is very influential on satisfaction (Kring \& Gordon, 1998), contributing to their loyalty. Consequently, the loyalty of females remained stronger because it was based on the level of loyalty and intention to move (hijrah).

Future studies in consumer behavior, especially loyalty, need to build a path in customer loyalty. There is a need to map the determinant variables of loyalty, especially within the financial services industry. Pathways could be mapped about the perspective of loyalty in attitude, behavioral, and integrative loyalty. Studies may consider the moderating effects of other demographic factors such as education and income in the future.

Despite the insightful findings, this study had various limitations. First, the focus was on the Indonesian Islamic bank customers, meaning that the sample was not entirely typical of the Muslim population. Therefore, future studies should test the relationship among the variables involving respondents all over the Indonesian provinces to obtain a better and more representative model result. Second, the focus was on hijrah intention role and satisfaction as the drivers of loyalty towards Islamic banks, yet many other variables, such as image and value, influence customer loyalty.

\section{ACKNOWLEDGEMENT}

This paper could be well conducted with the tremendous support from our respondents. Our colleagues especially at IAIN, have patiently provided corrections, especially regarding language and gender issues. Their enthusiasm, knowledge sharing and concern have inspired us to make this paper publishable.

\section{REFERENCES}

Abou-Youssef, M. M. H., Kortam, W., Abou-Aish, E., \& El-Bassiouny, N. (2015). Effects of religiosity on consumer attitudes toward Islamic banking in Egypt. International Journal of Bank Marketing, 33(6), 786-807. https://doi.org/10.1108/IJBM02-2015-0024

Abror, A., Patrisia, D., Engriani, Y., Evanita, S., Yasri, Y., \& Dastgir, S. (2019). Service quality, religiosity, customer satisfaction, customer engagement and Islamic bank's customer loyalty. Journal of Islamic Marketing, 11(6), 1691-1705. https://doi.org/10.1108/JIMA-03-2019-0044

Aldas-Manzano, J., Ruiz-Mafe, C., Sanz-Blas, S., \& Lassala-Navarré, C. (2011). Internet banking loyalty: Evaluating the role of trust, satisfaction, perceived risk and frequency of use. The Service Industries Journal, 31(7), 1165-1190. https://doi. org/10.1080/02642060903433997

Assaker, G., Hallak, R., Assaf, A. G., \& Assad, T. (2015). Validating a structural model of destination image, satisfaction, and loyalty across gender and age: Multigroup analysis with PLS-SEM. Tourism Analysis, 20(6), 577-591. https://doi.org/10.3727/10835421 5X14464845877797

Babin, B. J., \& Boles, J. S. (1998). Employee behavior in a service environment: A model and test of potential differences between men and women. Journal of Marketing, 62(2), 77-91. https://doi. org/10.1177/002224299806200206 
Bei, L., \& Chiao, Y. (2006). The determinants of customer loyalty: An analysis of intangible factors in three service industries. International Journal of Commerce and Management, 16(3/4), 162-177. https://doi.org/10.1108/10569210680000215

Bloemer, J., de Ruyter, K., \& Peeters, P. (1998). Investigating drivers of bank loyalty: The complex relationship between image, service quality and satisfaction. International Journal of Bank Marketing, 16(7), 276-286. https://doi. org/10.1108/02652329810245984

Bloemer, JoséM. M., \& Kasper, H. D. P. (1995). The complex relationship between consumer satisfaction and brand loyalty. Journal of Economic Psychology, 16(2), 311-329. https:// doi.org/10.1016/0167-4870(95)00007-B

Chawla, D., \& Joshi, H. (2018). The moderating effect of demographic variables on mobile banking adoption: An empirical investigation. Global Business Review, 19(3_suppl), S90-S113. https:// doi.org/10.1177/0972150918757883

Choi, Y. (2009). Religion, religiosity, and South Korean consumer switching behaviors. Journal of Consumer Behaviour, 9(3), 157-171. https:// doi.org/10.1002/cb.292

Cronin, J. J., Brady, M. K., \& Hult, G. T. M. (2000). Assessing the effects of quality, value, and customer satisfaction on consumer behavioral intentions in service environments. Journal of Retailing, 76(2), 193-218. https://doi. org/10.1016/S0022-4359(00)00028-2

Cross, S. E., Bacon, P. L., \& Morris, M. L. (2000). The relational-interdependent self-construal and relationships. Journal of Personality and Social Psychology, 78(4), 791-808. https://doi. org/10.1037/0022-3514.78.4.791

Dick, A. S., \& Basu, K. (1994). Customer loyalty: Toward an integrated conceptual framework. Journal of the Academy of Marketing Science, 22(2), 99-113. https://doi. org/10.1177/0092070394222001
Ergeneli, A., \& Arıkan, S. (2002). Gender differences in ethical perceptions of salespeople: An empirical examination in Turkey. Journal of Business Ethics, 40, 247-260. https://doi. org/10.1023/A:1020550916408

Fischer, E., \& Arnold, S. J. (1994). Sex, gender identity, gender role attitudes, and consumer behavior. Psychology and Marketing, 11(2), 163182. https://doi.org/10.1002/mar.4220110206

Fournier, S., \& Mick, D. G. (1999). Rediscovering satisfaction. Journal of Marketing, 63(October), 5-23. https://doi.org/10.1177\% 2F002224299906300403

Gefen, D., Straub, D., \& Boudreau, M.-C. (2000). Structural Equation Modeling and regression: Guidelines for research practice. Communications of the Association for Information Systems, 4. https://doi.org/10.17705/1CAIS.00407

Glavee-Geo, R., Shaikh, A. A., \& Karjaluoto, H. (2017). Mobile banking services adoption in Pakistan: Are there gender differences? International Journal of Bank Marketing, 35(7), 1090-1114. https://doi.org/10.1108/IJBM-092015-0142

Haider, M. J., Changchun, G., Akram, T., \& Hussain, S. T. (2018). Exploring gender effects in intention to Islamic mobile banking adoption: An empirical study. Arab Economic and Business Journal, 13(1), 25-38. https://doi.org/10.1016/j. aebj.2018.01.002

Hair, J. F., Sarstedt, M., Ringle, C. M., \& Gudergan. (2018). Advanced issues in Partial Least Squares Structural Equation Modeling. Sage.

Haron, S., Ahmad, N., \& Planisek, S. L. (1994). Bank patronage factors of Muslim and nonMuslim customers. International Journal of Bank Marketing, 12(1), 32-40. https://doi. org/10.1108/02652329410049599

Hoque, M. E., Hassan, M. K., Hashim, N. M. H. N., \& Zaher, T. (2019). Factors affecting Islamic 
banking behavioral intention: The moderating effects of customer marketing practices and financial considerations. Journal of Financial Services Marketing, 24(1-2), 44-58. https://doi. org/10.1057/s41264-019-00060-x

Iacobucci, D., \& Ostrom, A. (1993). Gender differences in the impact of core and relational aspects of services on the evaluation of service encounters. Journal of Consumer Psychology, 2(3), 257-286. https://doi.org/doi:10.1016/ S1057-7408(08)80017-4

Jin, N. (Paul), Line, N. D., \& Goh, B. (2013). Experiential value, relationship quality, and customer loyalty in full-service restaurants: The moderating role of gender. Journal of Hospitality Marketing \& Management, 22(7), 679-700. https://doi.org/10.1080/19368623.2013.723799

Johnson, M. C., \& Morris, R. G. (2008). The moderating effects of religiosity on the relationship between stressful life events and delinquent behavior. Journal of Criminal Justice, 36(6), 486-493. https://doi.org/10.1016/j. jcrimjus.2008.09.001

Johnson, M. D., Herrmann, A., \& Huber, F. (2006). The evolution of loyalty intentions. Journal of Marketing, 70(2), 122-132. https://doi. org/10.1509/jmkg.70.2.122

Jones, T. O. (1996). Why satisfied customers defect. Journal of Management in Engineering, 12(6), 11-11. https://doi.org/10.1061/(ASCE)0742597X(1996)12:6(11.2)

Kalinić, Z., Liébana-Cabanillas, F. J., Muñoz-Leiva, F., \& Marinković, V. (2019). The moderating impact of gender on the acceptance of peer-topeer mobile payment systems. International Journal of Bank Marketing, 38(1), 138-158. https://doi.org/10.1108/IJBM-01-2019-0012

Karatepe, O. M., \& Tekinkus, M. (2006). The effects of work-family conflict, emotional exhaustion, and intrinsic motivation on job outcomes of front-line employees. International Journal of Bank Marketing, 24(3), 173-193. https://doi. org/10.1108/02652320610659021

Kashif, M., Wan Shukran, S. S., Rehman, M. A., \& Sarifuddin, S. (2015). Customer satisfaction and loyalty in Malaysian Islamic banks: A PAKSERV investigation. International Journal of Bank Marketing, 33(1), 23-40. https://doi.org/10.1108/ IJBM-08-2013-0084

Kaynak, E., \& Harcar, T. D. (2005). American consumers' attitudes towards commercial banks: A comparison of local and national bank customers by use of geodemographic segmentation. International Journal of Bank Marketing, 23(1), 73-89. https://doi. org/10.1108/02652320510577375

Kishada, Z. M. E. (2013). Factors affecting customer loyalty in Islamic banking: Evidence from Malaysian banks. International Journal of Business and Social Science, 4(7), 264-273. https://doi.org/10.30845/ijbss

Kring, A. M., \& Gordon, A. H. (1998). Sex differences in emotion: Expression, experience, and physiology. Journal of Personality and Social Psychology, 74(3), 686-703. https://psycnet.apa. org/doi/10.1037/0022-3514.74.3.686

Kwateng, K. O., Atiemo, K. A. O., \& Appiah, C. (2019). Acceptance and use of mobile banking: An application of UTAUT2. Journal of Enterprise Information Management, 32(1), 118151. https://doi.org/10.1108/JEIM-03-2018-0055

Ladhari, R., \& Leclerc, A. (2013). Building loyalty with online financial services customers: Is there a gender difference? Journal of Retailing and Consumer Services, 20(6), 560-569. https://doi. org/10.1016/j.jretconser.2013.07.005

Lai, T. L. (2004). Service quality and perceived value's impact on satisfaction, intention and usage of short message service (SMS). Service Quality, 56, 353-368. https://doi.org/10.1023/ B:ISFI.0000046377.32617.3d 
Leverin, A., \& Liljander, V. (2006). Does relationship marketing improve customer relationship satisfaction and loyalty? International Journal of Bank Marketing, 24(4), 232-251. https://doi. org/10.1108/02652320610671333

Lubis, A., Dalimunthe, R., Absah, Y., \& Fawzeea, B. K. (2021). The effect of corporate communication and service quality on customer loyalty and satisfaction in Sharia banking. The Journal of Asian Finance, Economics and Business, 8(3), 1267-1274. https://doi.org/10.13106/ JAFEB.2021.VOL8.NO3.1267

Matzler, K., Füller, J., Renzl, B., Herting, S., \& Späth, S. (2008). Customer satisfaction with Alpine ski areas: The moderating effects of personal, situational, and product factors. Journal of Travel Research, 46(4), 403-413. https://doi. org/10.1177/0047287507312401

McKinney, V., Yoon, K., \& Zahedi, F. (2002). Satisfaction: An expectation and disconfirmation approach. Information Systems Research, 13(3), 296-315. https://doi.org/10.1287/ isre.13.3.296.76

Meesala, A., \& Paul, J. (2018). Service quality, consumer satisfaction and loyalty in hospitals: Thinking for the future. Journal of Retailing and Consumer Services, 40, 261-269. https://doi. org/10.1016/j.jretconser.2016.10.011

Melnyk, V., Stijn M.J. van, O., \& Bijmolt, T. H. A. (2009). Are women more loyal customers than men? Gender differences in loyalty to firms and individual service providers. Journal of Marketing, 73(4), 82-96. https://doi. org/10.1509\%2Fjmkg.73.4.082

Mohamed, N., Taheri, B., Farmaki, A., Olya, H., \& Gannon, M. J. (2020). Stimulating satisfaction and loyalty: Transformative behaviour and Muslim consumers. International Journal of Contemporary Hospitality Management, 32(9), 2903-2923. https://doi.org/10.1108/ IJCHM-04-2020-0330
Mohsan, F., Nawaz, M. M., Khan, M. S., Shaukat, Z., \& Aslam, N. (2011). Impact of customer satisfaction on customer loyalty and intentions to switch: Evidence from banking sector of Pakistan. International Journal of Business and Social Science, 2(16), 8.

Mosahab, R., Mahamad, O., \& Ramayah, T. (2010). Service quality, customer satisfaction and loyalty: A test of mediation. International Business Research, 3(4). https://doi.org/10.5539/ ibr.v3n4p72

Muniz, A. M., \& O'Guinn, T. C. (2001). Brand community. Journal of Consumer Research, 27(4), 412-432. https://doi.org/10.1086/319618

Ndubisi, N. O. (2006). Effect of gender on customer loyalty: A relationship marketing approach. Marketing Intelligence \& Planning, 24(1), 4861. https://doi.org/10.1108/02634500610641552

Noble, S. M., Griffith, D. A., \& Adjei, M. T. (2006). Drivers of local merchant loyalty: Understanding the influence of gender and shopping motives. Journal of Retailing, 82(3), 177-188. https://doi. org/10.1016/j.jretai.2006.05.002

Ohtomo, S., \& Hirose, Y. (2007). The dual-process of reactive and intentional decision-making involved in eco-friendly behavior. Journal of Environmental Psychology, 27(2), 117-125. https://doi.org/10.1016/j.jenvp.2007.01.005

Oliver, R. L. (1999). Whence consumer loyalty? Journal of Marketing, 63(Special issue), 3344. https://doi.org/10.1177\%2F00222429990 634 s 105

Panther, T., \& Farquhar, J. D. (2004). Consumer responses to dissatisfaction with financial service providers: An exploration of why some stay while others switch. Journal of Financial Services Marketing, 8(4), 343-353. https://doi. org/10.1057/palgrave.fsm.4770131

Parasuraman, A., Berry, L. L., \& Zeithaml, V. A. (1993). More on improving service quality 
measurement. Journal of Retailing, 69(1), 140-147. https://doi.org/10.1016/S00224359(05)80007-7

Powell, M., \& Ansic, D. (1997). Gender differences in risk behaviour in financial decision-making: An experimental analysis. Journal of Economic Psychology, 18(6), 605-628. https://doi. org/10.1016/S0167-4870(97)00026-3

Ramanathan, R., Di, Y., \& Ramanathan, U. (2016). Moderating roles of customer characteristics on the link between service factors and satisfaction in a buffet restaurant. Benchmarking: An International Journal, 23(2), 469-486. https:// doi.org/10.1108/BIJ-01-2015-0012

Rehman, A., \& Shabbir, M. S. (2010). The relationship between religiosity and new product adoption. Journal of Islamic Marketing, 1(1), 63-69. https://doi.org/10.1108/17590831011026231

Riyadi, S. (2021). The effects of image, brand and quality on customer loyalty of Sharia banking. The Journal of Asian Finance, Economics and Business, 8(3), 1315-1325. https://doi. org/10.13106/JAFEB.2021.VOL8.NO3.1315

Rufín, R., Medina, C., \& Rey, M. (2012). Adjusted expectations, satisfaction and loyalty development. The Service Industries Journal, 32(14), 2185-2202. https://doi.org/10.1080/026 42069.2011.594874

Saeed, K. A., \& Abdinnour-Helm, S. (2008). Examining the effects of information system characteristics and perceived usefulness on post adoption usage of information systems. Information \& Management, 45(6), 376-386. https://doi.org/10.1016/j.im.2008.06.002

Saleh, M. A., Quazi, A., Keating, B., \& Gaur, S. S. (2017). Quality and image of banking services: A comparative study of conventional and Islamic banks. International Journal of Bank Marketing, 35(6), 878-902. https://doi.org/10.1108/IJBM08-2016-0111
Sánchez-Hernández, R. M., Martínez-Tur, V., Peiró, J. M., \& Moliner, C. (2010). Linking functional and relational service quality to customer satisfaction and loyalty: Differences between men and women. Psychological Reports, 106(2), 598-610. https://doi.org/10.2466/pr0.106.2.598-610

Soelasih, Y., \& Sumani, S. (2021). The effect of wordof-mouth on purchase intention: A case study of low-cost carriers in Indonesia. The Journal of Asian Finance, Economics and Business, 8(4), 433-440. https://doi.org/10.13106/JAFEB.2021. VOL8.NO4.0433

Suhartanto, D., Gan, C., Sarah, I. S., \& Setiawan, S. (2019). Loyalty towards Islamic banking: Service quality, emotional or religious driven? Journal of Islamic Marketing, 11(1), 66-80. https://doi.org/10.1108/JIMA-01-2018-0007

Tiliouine, H., \& Belgoumidi, A. (2009). An exploratory study of religiosity, meaning in life and subjective wellbeing in Muslim students from Algeria. Applied Research in Quality of Life, 4(1), 109-127. https://doi.org/10.1007/ s11482-009-9076-8

Venkatesan, R., Kumar, V., \& Bohling, T. (2007). Optimal customer relationship management using bayesian decision theory: An application for customer selection. Journal of Marketing Research, 44(4), 579-594. https://doi. org/10.1509/jmkr.44.4.579

Venkatesh, V., \& Morris, M. G. (2000a). Why don’t men ever stop to ask for directions? Gender, social influence, and their role in technology acceptance and usage behavior. MIS Quarterly, 24(1), 115-139. https://doi.org/10.2307/3250981

Venkatesh, V., \& Morris, M. G. (2000b). Why don't men ever stop to ask for directions? Gender, social influence, and their role in technology acceptance and usage behavior. MIS Quarterly, 24(1), 115-139. https://doi.org/10.2307/3250981 
Vyas, V., \& Raitani, S. (2014). Drivers of customers' switching behaviour in Indian banking industry. International Journal of Bank Marketing, 32(4), 321-342. https://doi.org/10.1108/IJBM-04-20130033

Wang, C. L., Sarkar, A., \& Sarkar, J. G. (2018). Building the holy brand: Towards a theoretical model of brand religiosity. International Journal of Consumer Studies, 42(6), 736-743. https://doi. org/10.1111/ijcs.12430

Warsame, M. H., \& Ireri, E. M. (2018). Moderation effect on mobile microfinance services in Kenya:An extended UTAUT model. Journal of Behavioral and Experimental Finance, 18, 6775. https://doi.org/10.1016/j.jbef.2018.01.008

Worthington, E. L., Wade, N. G., Hight, T. L., Ripley, J. S., McCullough, M. E., Berry, J. W., Schmitt, M. M., Berry, J. T., Bursley, K. H., \& O’Connor, L. (2011). Religious Commitment Inventory-10 [Data set]. American Psychological Association. https://doi.org/10.1037/t00512-000

Yavas, U., Babakus, E., \& Karatepe, O. M. (2008). Attitudinal and behavioral consequences of work-family conflict and family-work conflict: Does gender matter? International Journal of Service Industry Management, 19(1), 7-31. https://doi.org/10.1108/09564230810855699

Yi, Y., \& La, S. (2004). What influences the relationship between customer satisfaction and repurchase intention? Investigating the effects of adjusted expectations and customer loyalty. Psychology and Marketing, 21(5), 351-373. https://doi.org/10.1002/mar.20009
Yudiana (2021). Hijrah intention dan kepuasan dalam model hubungan religiusitas dan loyalitas nasabah bank syari'ah: Studi pada nasabah bank syari'ah di Indonesia (Hijrah intention and satisfaction in the relationship model of religiosity and customer loyalty in Islamic banks: A study on the Islamic banks' customers in Indonesia), Unpublished Dissertation, the Postgraduate Program of UIN Sunan. Kalijaga Yogyakarta.

Yudiana, F. E., Kusuma, H., \& Qizam, I. (2021). Hijrah intention and type of customer loyalty of Islamic banks in Indonesia. Iqtishadia, 14(1), 43-62. http://dx.doi.org/10.21043/iqtishadia. v14i1.10440

Zoghlami, A. T., Ben Yahia, K., \& Berraies, S. (2018). From mobile service quality evaluation to E-word-of-mouth: What makes the users of mobile banking applications speak about the bank?: The moderating role of brand reputation. International Journal of E-Services and Mobile Applications, 10(2), 36-57. https:// doi.org/10.4018/IJESMA.2018040103 